"Na, Duke, I'm right. I'll not apologize."

He was exceptional, then homeless.

I'm leaving the wild to itself.

The wheatear persuasion

(inside the dyke, a perfected nest).

The curlew urging

(her young urge into the ground).

The chorus reminding.

This country has been rich with them,

the birds that sing,

and those who are silent.

\title{
Roger Garfitt on Robin Munro
}

The title of Robin Munro's paperback collection, Shetland, like the World, neatly encapsulates ( significantly, the phrase used to be "puts in a nutshell") the relevance of making poetry out of the past and present of a particular place: namely, that in registering the pressures acting upon an area one is able to register, at least in part, the pressures active within the whole economic complex. Seen in this way, regionalism is the opposite of provincialism: it is a tactic for selecting from and comprehending the otherwise innumerable and incomprehensible interrelations of social and economic forces that compose, or are discomposing, the contemporary world; at the same time it is a way of registering a set of personal loyalties that are themselves part of the pressure. If this seems in itself an act of discomposition, I would argue that we are at a stage where we probably have to take apart in order to understand, to re-assess and later to re-compose. We are also at a stage where we have a certain duty to record and so to preserve.

In writing of Shetland and North-East Scotland, of the impact of the new oil industry upon the remains of an old subsistence economy, Robin Munro is able to focus in a particularly acute form the clash between past and present, a clash that he skillfully pinpoints in "Coastal Village" by transforming "the long ships," with their echo of the Vikings, into "freight and container ships." "Coastal Village" is well constructed around the fragility of the harebells, as an image of this northern, marine environment in the final days of a thousand-year phase, a clarity that can't last, an inscape soon to be torn by the sea-breath, the oil ships bringing change as once the Vikings did.

I'm not sure about "the caring harbour": I would have thought a harbour was by its very nature "caring." "Haven" has the implication even more strongly: "harbour" and "haven" are both Old English roots, but I see there's 
a Stonehaven just south of Aberdeen. Or, depending on the coast, why not the Shetland word "voe"? The mention of language roots brings me to my disquiet with "persuasions of air": this seems to have come in from another style, from Peter Scupham perhaps. The Latin root sits even more oddly in a stanza that has "Reath" and "braes." "Hustlings of air," the sea-wind's rising framing the still-calm harbour? There is a strength to be gained in regional poetry from preserving the native purity of the diction, as George Mackay Brown does and as Basil Bunting did most effectively in the first part of Briggflatts. I'm not sure there's such a crucial difference between Old English and Old Norse roots as Bunting suggests, but there's every distinction between these and the Latin roots, which Bunting brings in only where they combine a particular semantic resonance with hard consonants, "excrement ... meditate ... obliterate." Similarly "their inclination / in the sea-breath" seems a good use of a Latinate word, combining a slightly unusual sense, that makes one aware of the root, with an apt sound value (and a quite different sound value from "persuasions"). Again, this is an aspect of discomposition. Chaucer wrought Old English and Norman French into one language, and Shakespeare repeatedly gained his effects by pairing a concrete Saxon word with an abstract Latin one, but we are at a stage where an awareness of the roots of the language may be one way back into our own roots. Seamus Heaney discusses this in Wintering Out, and in his recent work I find him particularly scrupulous in drawing on words native to his landscape, or on terms derived from the archaeologists and linguists who have defined it.

To continue: "salmon cobble" sounds fine, but a note might be useful to tell us southrons whether this means a salmon boat or the appearance of a shoal in the water. "Well below the speed for dealing" focuses effectively on one of the vanishing qualities. "The Moravian village" is clear enough, but if the reference is to more than a personal memory, again a note or some re-writing to bring out the significance might be necessary. I like "heavy with clover" and "the grinding mussel paths": that last detail evokes a whole landscape and economy.

"Cottages / formed like a friendship": a more thoughtful invocation of sentiment than "the caring harbour," entertaining the pathetic fallacy only to reject it. Munro stresses that the cottages were built out of need, not for friendship: "when wanted for a time." The subsequent reversal, "till time is the reason," is acute: we construct from purely material motives towns and villages that then seem to gain some extra, non-material quality simply from the time that they have stood: in this case, a sense of mutual dependence, keeping company between sea and hill. The other side of this, though, is the suspicion that the community may now persist only by virtue of its existence: the timelessness of the second stanza here comes closer to feeling adrift. 
The direct speech that opens the fourth stanza is excellent, a hint of dialect in the speech rhythm, but I'm not so sure about "heaves her oldness / over the jumping North." "Heaves" is a bit heavy, she sounds pregnant. Perhaps she's stout, but "oldness" suggests thin. I can't guess at "the jumping North": the Aurora Borealis? But it's morning. And if you can have the Northern Lights in the morning, why not say the Northern Lights? I thought of compass needles juddering at the Pole, but why's the old lady got a compass? Is it simply the distant horizon? But there's that clarity. I'm inclined to settle for the oil boom, the activity of the ships, but I do find it an awkward phrase. A pity, because, although I can imagine "their sky blue confidence" being more subtly turned, the lines from here on seem almost flawless.

In “Ancestors” I admire Robin Munro's refusal to romanticise, either the past-"He was exceptional, then homeless"-or the present-"I shiver to recognise something of me / at Stevenston and Invergordon." There's the problem: we're all hybrids, part of us depends on the technology. I'm uncertain of "the still / of the created world." Does he mean the end result of pollution, the sterility of the created world? Or the still of the manufactured world? The second stanza has an admirable cadence, a cadence won out of the achieved simplicity of the language. The equation of the Highland Clearances with modern refugees seems apt, though I'm not sure if "decay" is the right word. "Their suffering / is in a body where the bones escape": I take it that the bones are the relics, the skeletal mills, the boat, and that he means the stuff of their lives, the sentient texture, has gone: only the bones escape. Seems a long way about. The description that follows, culminating in "this back end / of a century" is fine.

The realism falters, though, and suddenly abandons truth for sentiment with "May the wild protect us / from a stiffening of vision!" The poetry of genuine concern, which I believe this to be, just cannot afford this sort of rhetoric, whose terms bear no examination: no vision could be stiffer than that of the wild, which is totally conditioned by inherited and acquired reflexes, nor does the wild recognise any right to a love or a past: it is entirely selfish, totally preoccupied with survival. Only man cares for the existence of other species, and that's a recent development. Traditionally man has used the wild as an area in which to escape from responsibility, and this, I fear, is what Robin Munro does here. The wild cannot look after itself, because the wild is blind. Commerce will not look after itself, because commerce is blind. Commerce remains part of the wild in man, until informed and modified by human qualities. The adjustments to industrial processes necessary to conserve an environment are only made in response to sustained pressure from local opinion. I would expect Robin Munro, not as a poet but as a man, to be adding his voice to those of his neighbours: 
the relationship of his poetry to his participation in the community can only be that each should enrich the other.

I find these poems intelligently put together, but uneven in detail, which is why I have discussed them in detail, and not finally thought through. The elegiac note on which "Ancestors" ends will be our own elegy if we accept it, for beyond the immediate conservation issue lies the kind of participation we will all have to undertake in future if the developed world is to be habitable. Here a truer understanding of the wild should help us, for it is the one model we have of selfish individual impulses co-existing in balance: what we hear every morning in the dawn chorus is a negotiator's dream, a minute system of checks and balances set to music, a symphony of resolved demarcation disputes. When the arts of life become so intricate, poetry too must be informed in its protest, patient and meticulous in its celebration.

\section{Robin Munro Replies}

I like Roger Garfitt's discussion of the subject matter I use. All I'd add is that, while I appreciate the extra validity of certain themes, most of the time the themes impose themselves on me in my life.

The trouble with linguistic analysis is that there are so many factors at work when the poet selects his word. Even "select" sounds too deliberate for what often happens. The word nudges up to you. You give it momentary shelter. Later, when you examine all the possibilities in your language(s), this uninvited guest turns out to be the best.

In my use of words and structures I'm conscious of: sound (the rhythm and balance of phrases and syllables), meaning (the literal and the associated, the sub-logical connections that grow in the mind), then the use (how the word behaves in areas, situations), and finally the history (the linguistic elements, including roots).

I might insist on root purity if I was dealing with a past integrated culture. If I wanted absolute linguistic truth in the present, I would write in a true language, say the (thriving) Shetland language, or the (weakened) Mearns dialect of my village. Even then there might be Latinate words, vital to our senses, since we're the product of so many influences. What I try to do is maintain a speech pattern that is true to me or to my speaker in the poem. I use dialect on that basis.

Coble or cobble is the class of boat they use for salmon fishing here. I see "flat bottomed boat" is the Chambers definition. My English publishers ask me to gloss such words, and I agree. Not the Moravian village though, it's there to widen the particular to the whole existential ceremony of village life, happening at this moment there, here. Perhaps reading Skácel has given 
me a feeling of Moravian villages, but you can read in any inland region, experience, remembered.

Yet another side to the cottages-the simile may also say something about the nature of friendship.

It is the "jumping" North because of the Boom ( sic), things moving so fast the old woman wouldn't know where to tread. Maybe I'll hide her (round) identity by modifying "heaves."

In "Ancestors," "bones" also suggests to me the rock breaking through the surface of barren land.

In other associated poems I may work towards an understanding informed by (but not based on) social sense/faith. "Ancestors" is a factual background with some aspects of awareness and action. I hope readers will develop the themes. Roger Garfitt does. He can make value judgments about the "me" in the poem, as he can about my great-great-grandfather, the Clearances, or the present. He doesn't support acceptance. "Singing" and "being silent" can be understood in human terms.

The italicised lines are really an unanswerable prayer. Munro starts this sideways chant but has to give it up (“...”), for the first of Garfitt's reasons.

I think my view of nature is closer to Richard Jefferies than to Roger Garfitt. I completely reject his negative judgment on my poetry's "participation," and I can't agree with his conclusions.

\section{Gardening in Avernus / Roger Garfitt}

Evening in the turned earth. A night wind foxes the grass. Still through the late afternoon of stone the thin scent rises of a herb patch by the wall, and I am on a path of that other garden, where thyme is grey bush beyond the vines, reptile over the dry rocks.

Cicadas stir the leaf fall. The lich-owl pronounces dusk over shadowless cedars. The foraging pipistrelles enter meridian blue. A common scent of earth is the black ship across Ocean, 